\section{Jolly Sahni ${ }^{1}$}

Article info:

Received 19.08.2018.

Accepted 02.02.2019.

UDC $-005.331 / 332$

DOI - 10. 24874/IJQR13.02-03

\title{
ROLE OF QUALITY OF WORK LIFE IN DETERMINING EMPLOYEE ENGAGEMENT AND ORGANIZATIONAL COMMITMENT IN TELECOM INDUSTRY
}

\begin{abstract}
The value that Quality of work life ( $Q W L)$ brings to the workplace has long been established by several scholars, however, the impact of $Q W L$ on engagement and commitment levels of employees remains under investigated. The present empirical study is devoted to explore the quality of work life in telecom industry and examine its association with employee engagement and organization commitment. The data collected from a random sample of 312 employee working in Telecom industry of Saudi Arabia, was analysed through Descriptive statistics and Structural Equation Modeling (SEM). Evidence supports the significant relationship of quality of work life and organizational commitment, however, there is a weak link of quality of work life with employee engagement. This is the first study to explore the relationship among three important constructs of workplace; quality of work life, organizational commitment and employee engagement. Therefore, the study significantly contributes to the extant literature on Quality of work life.
\end{abstract}

Keywords: Quality of work life, Employee engagement, Organizational commitment, Job satisfaction, work-life balance

\section{Introduction}

Given the challenges of globalization, diversification, advancement in technology, frequent changes in employee attitude, organizations need to create a niche and succeed in the dynamic business environment. In this scenario, the human capital of organization is one of the few resources which can provide a competitive advantage to the organization in the form of committed and engaged employees. In order to have high performance level from employees, organizations are accountable to provide support to the employees at work. Furthermore, there is an all-round demand for developing the humanized job which can satisfy employee's higher needs, employ their higher skills and make them better employees, spouses and parents. This demand for redesigning has come to be known as Quality of Work Life, which embraces significant aspects of work including the work environment, monetary compensation for work, hours of work, scope of progression, benefits, welfare services etc. There is a strong need to replace the traditional job design with more enriched job designs which provide flexibility to the employees.

The importance of QWL has been comprehended in various studies (Martel \&

1 Corresponding author: Jolly Sahni

Email: jsahni@psu.edu.sa 
Dupuis, 2006; Sahni, 2017). The human resources of any organization are critical to achieve the goals and therefore, human resource policies and practices must have a strategic approach (Allui \& Sahni, 2016). Past studies indicate the positive relationship of job satisfaction with quality of work life (Koonmee et al., 2010; Noor \& Abdullah 2012). Similarly, Drobnic et al., (2010) propose that employees who have secure jobs would feel comfortable at the work place having a positive impact on their quality of life. Low quality of work life may affect the quality of services and organizational commitment as a whole. Therefore, Quality of work life may be considered as an umbrella term including job satisfaction, working conditions, opportunity for continuous growth, work life balance, stress management at work, social relationships, organizational culture and communication. Considering the different industries, telecom is one of the fastest growing and dynamic industries, which is considered to be demanding and stressful for employees due to the long working hours. The telecom industry is facing a transformation in the technology and services, which therefore challenges the telecom employees to work faster, more effectively, and efficiently. This requires the industry to be more vigilant and proactive in improving the quality of work life of their employees, which could help them, focus on work and adapt to the changes quickly.

Another important factor in the workplace is employee engagement which is a desirable workplace behavior known to produce positive outcomes. Researchers have explored the outcome of increased employee engagement like higher productivity, performance and commitment (Saks, 2006; Christian et al., 2011; Bailey et al., 2017; Bakker \& Albrecht, 2018). As a predictor of employee engagement, past studies have tested job characteristics, perceived organizational support, procedural and distributive justice. However, no study so far have linked quality of work life with the important workplace attitude; employee engagement.

Moreover, literature on QWL in the context of Saudi Arabia is limited because several studies are commonly related with only job satisfaction and in most of the studies, it is not clear how quality of work life of employees influences their engagement levels and organizational commitment. Therefore, the role of quality of work life as an antecedent to employee engagement and organizational commitment remains under investigated. Against this backdrop, the present empirical study explores the complex relationship between the three constructs; quality of work life, employee engagement and organizational commitment. Therefore, the study aims to achieve the following objectives:

1) To assess the perceived quality of work life among the telecom Industry employees.

2) To investigate the relationship of quality of work life and organizational commitment.

3) To study the relationship of quality of work life and employee engagement.

The remainder of paper is organized into four sections. Section two summarizes the review of relevant literature. Section three presents research methods while section four discusses the findings, section five concludes the paper with implications and area of future research. Introduction should provide a review of recent literature and sufficient background information to allow the results of the paper to be understood and evaluated. It should clearly explain the nature of the problem, previous work, purpose and contribution of the paper.

\section{Review of literature}

The literature review is covered in four sections which presents the past research on quality of work life (QWL), organizational commitment (OC) and employee engagement 
(EE). The last part briefly reviews the relationship studies conducted on these three constructs.

\subsection{Quality of worklife}

'Quality of work-life' refers to the favourableness or non-favourableness of a total job environment for the employees. The contribution of Walton (1973), Herzberg et al., (1959), Sirgy et al., (2001) and many others have paved the way for the development of new concepts and experimental process and thus evolved as the building blocks for Quality of work life (QWL). Through QWL programs organizations enrich jobs and create a working environment that is admirable for people as well as for economic health of the organization. It mainly includes aspects of work-related life such as wages, working hours, work environment, benefits and services, career prospects and human relations, which are related to worker satisfaction and motivation. It is imperative to enhance quality of work life as people spend more than fifty percent of their life time at workplaces. QWL can be seen as an approach to organizing work and managing people which ultimately improves the quality of life of employees. According to Walton (1973), the QWL plays a significant role in sustaining the human values that have been neglected in favour of technological growth and economic growth. Further, Mirvis and Lawler (1984) labelled equitable wages, opportunities for growth and safe working environment as the fundamental essentials of a good quality of work life. QWL incorporates two perspectives; first, the work related factors like relationship with co-workers or monetary benefits and second, the life related factor such as satisfaction with life and a state of general well-being (Danna \& Griffin, 1999; Tabassum et al., 2011).

Seashore (1975), Kahn (1981), Kalra and Ghosh (1984), affirmed that a significant byproduct of the approach to the quality of work life has been the identification of those aspects of jobs and work environments that impact most strongly upon the job satisfaction, job performance, and life-long well being of those who are so employed. The importance of need assessment for human motivation was analysed by Steininger (1994), the future of American firms depends on the concept that should be based upon the correct assessment of needs and motivation of its employees. The purpose of his study was to probe into the reasons of failure in implementing quality initiatives and assess the human motivation. It talks about the leaders and managers of most U.S companies are failing in their quality initiatives because they lack the understanding of the philosophical and psychological needs of employees. Motivation being the focus here, the author mentions all types of extrinsic, intrinsic motivators and different types of human needs. The scholars in industrialized nations of North America, Europe have played a primary role in these studies, followed by the contribution made by the writers of Asian countries such as India and Malaysia, in the field of QWL. The importance of QWL was also recognized by International Labor Organization (ILO) when in 1999 it introduced a new plan of "decent work" (ILO, 2001).

One of the integral facet of QWL is known to be work life balance. Many novel approaches to work life balance have been proposed so far. For example, Denton (1993) examined concept of 'Flextime', which according to him requires careful and systematic implementation resulting in increased productivity and high employee morale. Similarly, Bencivenga (1995) in his study lays emphasis on one of the important worklife intervention called 'compressed week' that fill an HR niche. Companies have found a new reason to see smiles on their employees faces. There is a huge volume of research building up on this subject and it points out that the return on investment of work-life programs can be significantly positive. Work life balance practices of organization reap positive results in the form of retained human 
capital (Deery, 2008). Rose et al., (2006) came up with a different relational research to determine the relationship of QWL with the career related variables. It suggests that people are more satisfied when their career provides them higher prestige, with better income and greater power. The predictor variables significant in explaining QWL in organizational climate are; career satisfaction, career achievement and career balance. The study shows a positive relationship concerning ambition and career achievement, QWL is linked to career development and career is evolving from such interaction of individual within the organization. Furthermore, QWL is also tested to yield financial results. A study by Ballou and Godwin (2007), emphasized on the novel relationship between QWL investment and the financial performance. There are three major findings of their work; first being the interrogation of the issues that why any company should spend to increase employee satisfaction. Second finding relates to the improving the work life quality, a list having common benefits is given that includes benefits like child-care resource, career counseling, elder care etc. Third finding is the investment in the future, as complexity in the economy of America is increasing; this investment in employee satisfaction becomes all the more important.

In the view point of Wagner and Harter (2006), an employee's perceived QWL is determined primarily by two factors, both of which are controllable under their immediate supervisor: first, the main QWL factor is feeling appreciated for performing meaningful work. Second, employees also want to feel like 'their work matters'. The term 'quality at work' was also addressed in various studies (Steinninger et al., 2003) which focused on finding out the new requirements of work environment for high quality services. Further, studies have examined QWL with regard to organizational development on performance and improvement in QWL (Ramstad, 2009). The role of QWL is also imperative in predicting stress and burnout among employees which may occur due to lack of resources and support from organization (Khaghanizadeh et al., 2008; Bragard et al., 2015). QWL is also closely related to the concept of employee loyalty and organizations organize employee loyalty programs to motivate employee and promote the best performers of the company to increase their commitment (Wahlberg et al., 2017). Especially, employee loyalty is considered to be significant in reducing the turnover and increase the employee retention (Dizaho \& Othman, 2013; Lu et al., 2016; Miller 2017). Since, enhancing quality of work life improves employee satisfaction and satisfied employees tend to be more loyal (Matzler \& Renzl, 2006), therefore QWL which generally improves satisfaction may result in employee loyalty as well. Past studies suggest that employee loyalty is directly influenced by the job characteristics, job satisfaction and employee empowerment (Chen, 2006; Kuo, et al., 2010; Turkyilmaz et al., 2011; Nayak et al., 2018). In a recent study by Yao et al., (2019), employee loyalty is found to be strongly related to organizational commitment. The evidence is found in their study that, both behaviour and attitudinal loyalty are the consequences of organizational commitment in the hotel industry. Similarly, studies have found the association of employee loyalty with employee engagement as well (Ibrahim \& Falasi, 2014).

\subsection{Organizational commitment}

Organizational commitment indicates the attitudes of members of organization towards the organization's values and goals. The experience an individual acquires while performing the multi-facet task at work place either strengthens his commitment or weakens it and influences the turnover intentions. Turnover has been a major issue in all companies in the past few years. High employee turnover is considered to be negative for organizations as they have to invest again in recruiting new employees and 
providing them training. In fact, turnover intention and turnover decisions may be a sign of low or decreased quality of working life.

In general, it is said that committed employees are better performers. Organization commitment simply reflect emotional attachment and feeling of obligation by the employee, it is a person's positive attitude towards their organization. Therefore, it is a psychological state of attachment (O'Reilly \& Chatman, 1986). Meyer and Allen (1997) developed a model of organizational commitment including affective, continuance and normative commitment. Rhoades et al., (2001), used five items from affective commitment scale (from Meyer and Allen, 1997) and one item related to pride in organization members and used this six-item scale to assess the relationship of commitment with perceived organizational support and turnover intentions. They found a strong association of affective commitment with both.

The subject of organizational commitment was further explored in relation to absenteeism, performance and turnover intentions (O'Reilly \& Chatman, 1986; Meyer and Allen 1997; Fu \& Deshpande, 2014). Studies have tested and validated the positive and significant relationship among employee engagement and organization commitment (Saks 2006; Hu et al., 2011). Albdour and Altarawneh, (2014), examine the relationship between job and organization engagement and organizational commitment and found a significant positive association of employee engagement with organization commitment on the sample frontline employees. However, none of the studies have explored the three constructs together; QWL, organizational commitment and employee engagement. In this study quality of work life is examined as a predictor for employee commitment and their decision to stay in the company for longer number of years.

\subsection{Employee Engagement}

Employee engagement has also received due attention in the recent past (Harter et al., 2002; Schaufeli et al., 2002; Saks 2006; Crawford et al., 2014; Bailey et al., 2017). Since companies around the world are facing high employee turnover, low job satisfaction and increased levels of absenteeism, employee engagement is seen as a solution and a strategy to retain employee and increase organizational effectiveness (Bhatnagar, 2007; Reijseger et al., 2017). The more engaged and involved the employees are in a job role, the more productive they will be and the more they will contribute to the growth of the organization.

Researchers have examined employee engagement as an important factor in the workplace which contributes positively to the organizational effectiveness like higher productivity, high level of citizenship behavior, performance (Robinson et al., 2004; Bakker \& Albrecht, 2018) and overall employee satisfaction and organizational commitment (Saks, 2006; Brunetto, et al., 2012). Moreover, at individual level, studies suggest that employee engagement also influences the happiness, a state of being happy, among employees (Stairs \& Galpin 2010; Othman et al., 2018). Sufficient evidence is marked in the literature for the utility of employee engagement in increasing organizational performance and positive employee outcome (Saks, 2006; Xanthopoulou et al., 2007; Reijseger et al., 2017). The opposite is also true, having disengaged employees results in negative outcomes for any organization.

Findings of studies considering the impact of disengaged employees on a country as a whole, suggest that the situation of employee engagement is not very promising across the globe. For example, a study on United States of America suggests that nearly half of its workforce is disengaged which result in loss of productivity and therefore financial loses to the country (Johnson, 2004; Bates, 2004). Similarly, Hooper (2006) studied the level of 
employee engagement in Australia and found that the disengaged employees cost around $\$ 31$ billion to the economy every year. Therefore, employee engagement is crucial for any country. QWL encompasses most of the work related facets which might have an influence on employee engagement.

\subsection{Linking Quality of work life, Organizational Commitment and Employee Engagement}

The value that QWL brings to the workplace has long been established (Nadler \& Lawler 1983). There is ample support found in the literature for the significance of quality of work life in attaining positive outcomes for organizations. QWL has been studied in relation to job related attitudes like, turnover intention, employee commitment, organizational effectiveness (Havlovic, 1991; Huang et al., 2007; Koonmee et al., 2010; Sahni, 2016). For example, the findings of a study by Huang et al., (2007) suggests that all dimension of QWL positively affects the commitment level shown by auditors in Taiwanese public accounting firms, which consequently affects the turnover intentions to a great extent. Moreover, it is believed that QWL enhances employee's self-esteem by providing them the basic facilities at work and redesigning the work to be humanised at the same time proving that each employee's contribution matters to the organization in achieving its goals (Walton, 1974; Carlson, 1980; Nachmias, 1988; Hian and Einstein, 1990).

Similarly, studies have established a strong link of employee engagement with positive work outcomes (Chalofsky \& Krishna, 2009). Organizational commitment and employee engagement are also studied as important workplace factors. However, only a handful studies have explored the connection between the two constructs; quality of work life and employee engagement (Parkes \& Langford 2008; Kanten \& Sadullah, 2012), and none of the studies have explored the three constructs together; QWL, organizational commitment and employee engagement.

Therefore, to close this gap the present study aims to explore this relationship by postulating the following hypothesis:

H1: Overall Quality of work life will be positively related to organizational commitment.

H2: Employees who perceive high quality of work life will display higher levels of engagement. Therefore, it is hypothesized that positive relationship exists between $Q W L$ and employee engagement.

H3: Highly engaged employee will depict higher organizational commitment.

\section{Research methodology}

The research uses cross-sectional survey research design approach. The data has been collected through self-administered questionnaire from a random sample of 312 employee working in Telecom industry of Saudi Arabia. Only a handful of companies in the telecom sector dominate the Industry, therefore a random sample was selected from four different telecom companies during January- April 2018. Survey questionnaire were sent to 600 employees however, only 312 fully complete surveys were returned with a response rate of fifty-two percent. Descriptive statistics and Structural Equation Modeling (SEM) is used in analyzing the data.

\subsection{Survey Instrument}

There are four sections in the questionnaire; Section A ascertains information on demographic profile, section B assess quality of work life while section $\mathrm{C}$ examines employee engagement and section D assess their organizational commitment. A five point likert scale $(1=$ Strongly disagree to $5=$ Strongly Agree) was used to measure all items. Data is collected and analysed to find answer to research questions; (a) what is the current status of quality of work life prevailing Telecom Industry? (b) what is the 
relationship of quality of work life and organizational commitment? and (c) does quality of work life influences employee engagement?

Quality of work life: The survey instrument was prepared after a thorough literature review. Items were adapted from previous validated instruments. The QWL survey consists of 27 items covering seven variables; job satisfaction, working conditions, opportunity for growth, work life balance, stress management, social relationship and organizational culture and communication. Sample item being "My supervisor/Manager is concerned about the welfare happiness of those working under him or her".

Employee engagement: To investigate the employee engagement, study used the most widely adopted instrument the Utrecht Work Engagement Scale developed by Schaufeli et al., (2002), which is validated by large number of studies as well (Schaufeli 2014; Bailey et al., 2017). The scale has 17 items which assess vigour, dedication and absorption. An example of sample item is "When I am working, I forget everything else around me".

Organizational commitment: Respondents rated their organizational commitment with six items used by Rhoades et al., (2001) in their study. A sample item being "I am more than satisfied to work at my organization until I retire".

\subsection{Sample}

Using survey approach, data is collected from a random sample of full time employees working in Telecom sector of Saudi Arabia. Questionnaires were sent to 500 employees, however, only 312 completely filled surveys were returned. All questionnaires were accompanied with a covering letter stating the purpose of the study, as well as its voluntary and confidential nature.

\subsection{Data Analysis}

Data is analyzed using SPSS 22.0 and descriptive statistics is presented. To test the research model (Figure 1), structural equation modeling (SEM) method is also applied. The reliability of the scale was estimated with the help of internal consistency method requiring the application of Cronbach's Alpha Coefficient (a). Table 1 depicts the reliability statistics for all the subscales used in this study.

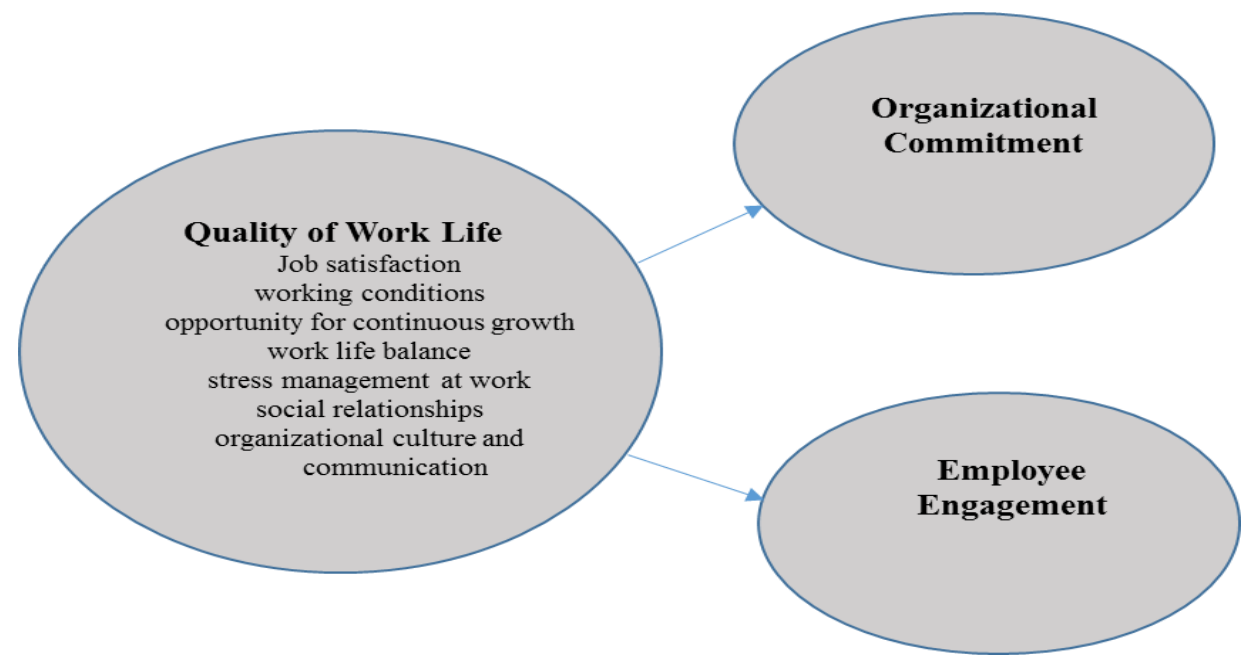

Figure 1. Research Model 
Table 1. Reliability statistics

\begin{tabular}{|l|c|c|}
\hline QWL Scale & Items & Cronbach's Alpha \\
\hline Job Satisfaction & 4 & .715 \\
\hline Working Conditions & 3 & .759 \\
\hline Opportunity for Growth & 3 & .683 \\
\hline Work life Balance & 2 & .601 \\
\hline Stress Management & 3 & .771 \\
\hline Social Relationship within Organization & 5 & .686 \\
\hline Organizational culture and communication & 7 & .833 \\
\hline Employee engagement scale & Items & Cronbach's Alpha \\
\hline Employee engagement & 17 & .835 \\
\hline Organizational commitment scale & Items & Cronbach's Alpha \\
\hline Organizational commitment & 6 & .714 \\
\hline
\end{tabular}

\section{Findings and disussion}

In this section the profile of participants, variables and descriptive statistics is presented. Inter-correlation among variables are reported. The results of SEM are presented next.

\subsection{Profile of participants}

Table 2 presents a brief profile of participants. Out of the total sample of 312 employees, only 51 were female, majority of them were between 21-30 years of age (50.7 percent) followed by $31-40$ years (41.7 percent), and 41-50 years (8.32 percent). The majority of respondents had bachelor's degree $(60.5$ percent) and 26 percent had a master's degree as educational qualification. In terms of work experience, 20.8 percent of respondent had less than one-year experience, 43.6 percent had experience between one to three years and only 13.7 percent had more than 5 years' experience.

Table 2. Profile of respondents

\begin{tabular}{|c|c|c|}
\hline Employee profile & Number & Percentage \\
\hline \multicolumn{3}{|c|}{ GENDER } \\
\hline Male & 261 & 83.65 \\
\hline Female & 51 & 16.32 \\
\hline 0-1 Years & 65 & 20.83 \\
\hline 1-3 Years & 136 & 43.58 \\
\hline 3-5 Years & 68 & 21.79 \\
\hline More than 5 Years & 43 & 13.78 \\
\hline \multicolumn{3}{|c|}{ TENURE/EXPERIENCE } \\
\hline Under 21 Years & 0 & 0 \\
\hline 21-30 Years & 156 & 50.68 \\
\hline 31-40 Years & 129 & 41.74 \\
\hline 41-50 Years & 26 & 8.32 \\
\hline 51 or Older & 1 & 0.32 \\
\hline \multicolumn{3}{|c|}{ QUALIFICATION } \\
\hline Diploma & 42 & 13.46 \\
\hline Graduate & 189 & 60.57 \\
\hline Post Graduate & 81 & 25.96 \\
\hline
\end{tabular}


Table 2. Profile of respondents (Continued)

\begin{tabular}{|c|c|c|}
\hline \multicolumn{3}{|c|}{ JOB TYPE } \\
\hline Full Time & 312 & 100 \\
\hline Part Time & 0 & 0 \\
\hline \multicolumn{3}{|c|}{ PROMOTIONS AVAILED } \\
\hline None & 87 & 27.88 \\
\hline One & 106 & 33.97 \\
\hline Two & 64 & 20.51 \\
\hline Three & 24 & 7.69 \\
\hline More Than Three & 31 & 9.93 \\
\hline
\end{tabular}

\subsection{Descriptive statistics}

In order to describe the responses for the major variables, descriptive statistics such as mean and standard deviation for all independent and dependent variables were obtained. Table 3 depicts the results of mean and standard deviation of QWL, organizational commitment and employee engagement dimensions.

Table 3. Mean, SD, inter-cirrelation among constructs

\begin{tabular}{|l|l|l|l|l|l|l|l|l|l|l|l|}
\hline Variable & Mean & SD & JS & WC & OG & WLB & SFW & SR & OCC & QWL & OC \\
\hline $\begin{array}{l}\text { Job } \\
\text { Satisfaction(JS) }\end{array}$ & 3.83 & 0.55 & 1 & & & & & & & & \\
\hline $\begin{array}{l}\text { Working } \\
\text { Conditions(WC) }\end{array}$ & 4.36 & 1.21 & 0.69 & 1 & & & & & & & \\
\hline $\begin{array}{l}\text { Opportunities for } \\
\text { Growth(OG) }\end{array}$ & 3.05 & 1.30 & 0.65 & 0.64 & 1 & & & & & & \\
\hline $\begin{array}{l}\text { WorkLife } \\
\text { Balance(WLB) }\end{array}$ & 3.40 & 1.11 & 0.44 & 0.47 & 0.46 & 1 & & & & & \\
\hline $\begin{array}{l}\text { StressFree } \\
\text { work(SFW) }\end{array}$ & 3.30 & 0.85 & 0.48 & 0.47 & 0.45 & 0.37 & 1 & & & & \\
\hline $\begin{array}{l}\text { Social } \\
\text { Relationships(SR) }\end{array}$ & 3.08 & 1.02 & 0.67 & 0.62 & 0.61 & 0.47 & 0.47 & 1 & & & \\
\hline $\begin{array}{l}\text { Org. Culture and } \\
\text { Comm (OCC) }\end{array}$ & 3.53 & 1.03 & 0.68 & 0.60 & 0.59 & 0.37 & 0.46 & 0.71 & 1 & & \\
\hline $\begin{array}{l}\text { Overall Quality } \\
\text { of work } \\
\text { life(QWL) }\end{array}$ & 3.50 & 0.91 & 0.81 & 0.70 & 0.84 & 0.59 & 0.65 & 0.90 & 0.82 & 1 & \\
\hline $\begin{array}{l}\text { Organizational } \\
\text { commitment } \\
\text { (OC) }\end{array}$ & 3.91 & 0.51 & 0.65 & 0.61 & 0.71 & 0.67 & 0.55 & 0.62 & 0.45 & 0.79 & 1 \\
\hline $\begin{array}{l}\text { Employee } \\
\text { engagement (EE) }\end{array}$ & 3.63 & 0.43 & 0.48 & 0.38 & 0.45 & 0.46 & 0.41 & 0.52 & 0.23 & 0.47 & 0.37 \\
\hline
\end{tabular}

Thus it is clear from the Table that the mean of all QWL variables fall in between 3.08 and 4.36 out of maximum score of 5.0. Interestingly, out of all seven dimensions, job satisfaction, working conditions and work life balance and scored the highest mean score and contributed significantly to QWL. As in the case of organizational commitment and employee engagement variables, the mean score falls between 3.63 and 3.91.

\subsection{Prevailing levels of QWL}

QWL is considered as one of the prerequisites of the working environment, therefore we assume that a minimum level of QWL should prevail in the organizations. Especially in the current scenario, when the world is moving towards more inclusive workplace it is imperative to offer conducive and supportive work setting for all types of employees (Barak, 2016). The minimum level is assumed to be mean value of 3 , out of 5 (that 
is $60 \%$ ) for any variable would be considered as satisfactory. The findings depict that the Telecom companies have different levels of QWL based on their size and growth pattern. In addition, the companies where the QWL levels are reported high, they are large sized companies and follow global standards and benchmarks of QWL. Based on the findings, QWL is perceived as high by more than 70 percent of employees which reflects that a high quality of work life prevails in the Telecom Industry. However, at the same time 30 percent of employees cannot be ignored, who registered their disappointment with the different facets of work life. Mainly, employees were not satisfied with the availability of opportunities for growth and the social relationship dimensions of QWL.

\subsection{QWL, Organizational commitment and Employee engagement}

As shown in Table 3, organizational commitment and employee engagement, both are positively related with quality of work life, however, the relationship between QWL and employee engagement is not very strong. The results of coefficient of correlation between QWL and Organizational commitment were found to be 0.79 significant at .01 levels. The value is significant and positive, depicting a direct and significant relationship of QWL with Organizational commitment in the Telecom companies. It suggests that high level of QWL results into high level of commitment and low levels of QWL may affect the Organizational commitment in an adverse manner. Having a good standard of work life depicts a positive impact on their decision to stay in the company for longer number of years. In this study quality of working life has been found to be a key predictor of organizational commitment. Their commitment level was mainly determined by opportunities for growth and work life balance (dimensions of QWL). In other words, in order to bring about a change in the level of commitment of employees, organizations have to improve the growth opportunities as well as reframe the work life balance policies. Accordingly, it can be stated that employee's commitment is least influenced by the workload, as the generation today is willing to work hard but desires the appropriate reimbursement and appreciation for the hard work. Overall, the High Performance Work Practices (HPWP) are suggested to significantly increase the employee commitment.

While, the coefficient of correlation between QWL and employee engagement is found to be only $0.471,(\mathrm{p}<0.01)$ which is not very high but still positive. It depicts that all the facets of QWL are positively related with engagement but the strongest relationship exist between social relationship and employee engagement $(\mathrm{r}=0.52, \quad \mathrm{p}<0.01)$ followed by Job satisfaction $(\mathrm{r}=0.48, \mathrm{p}<0.01)$ and work life balance $(r=0.46, p<0.01)$. And the least relationship was found between organizational culture and communication and employee engagement $(r=0.23, \mathrm{p}<0.01)$. Depicting that employee engagement is most influenced by the satisfaction employee gains in his job and the balance with work and personal life.

To analyse the relationship between different constructs studied, Partial least square approach has been applied through SmartPLS (Ringle et al., 2005). It is reflected that convergent validity is achieved if loadings of the measures to their respective constructs is at least 0.60 (Bagozzi \& Yi, 1988). The composite reliability (CR) of all constructs were found to be at least 0.6 and average variance extracted (AVE) was above 0.5 (Fornell \& Larcher, 1981). The research use quality of work life, organizational commitment and employee engagement as second order factors.

\subsection{Patial least square}

SEM was performed to test the hypothesis and examine the relationship between the three constructs of quality of work life, organizational commitment and employee 
engagement. The result is depicted in Figure 2. H1 suggests that overall quality of work life will be positively related to organizational commitment. Findings suggest a significant relationship $(B=0.163$, t-stat $=2.18)$, supporting the hypothesis, therefore, there exists a favourable and significant relationship between quality of work life (QWL) and organizational commitment (OC). $\mathrm{H} 2$ proposes that positive relationship exists between QWL and employee engagement; support was found for the positive relationship $(\beta=0.108$, t-stat $=1.80)$. Therefore, employees who perceive high quality of work life also displayed higher levels of engagement. $\mathrm{H} 3$ suggests that highly engaged employee will depict higher organizational commitment. Support was found for this relationship $(B=0.164$, $t$-stat $=$ 2.563). Organizational commitment is explained through 62.5 percent variation contributed to overall QWL, while only 22.1 percent of variation in employee engagement is explained by overall QWL.

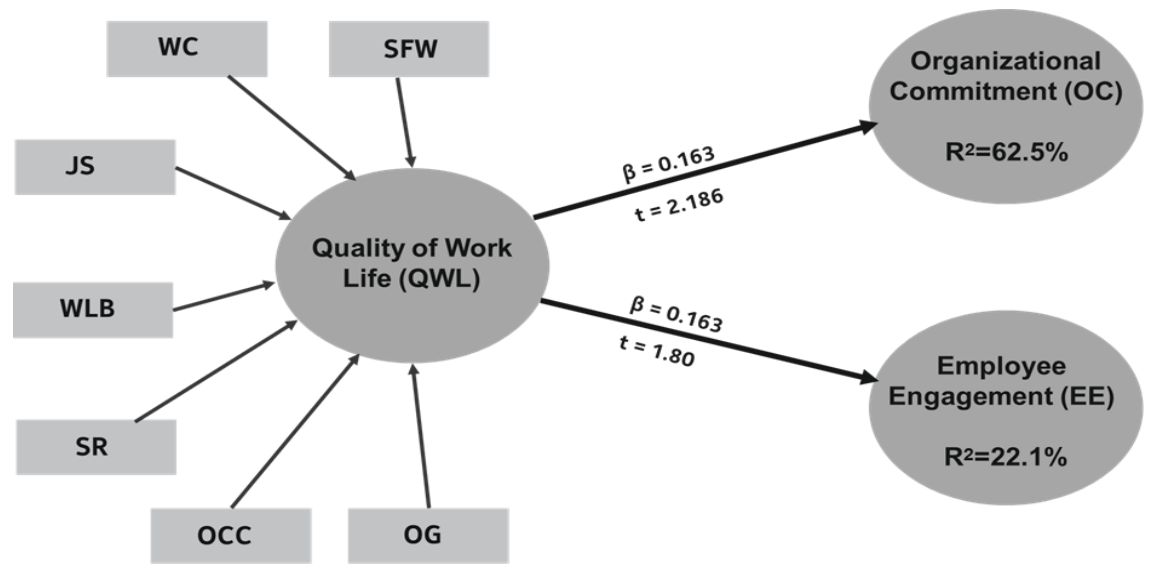

Figure 2. Structural equation model

The findings suggest that there exists a significant and positive relationship between quality of work life, organizational commitment and employee engagement and therefore, to increase commitment and engagement among employees, organizations must enhance the quality of work life by providing stress free, supportive, satisfying workplace in addition to growth opportunities and cohesive interpersonal relationship. Every employee is crucial for organization and contributes to the organizational effectiveness. Taking into account employee's skills, experience, motivation, some play a better role than others. Thus, efforts to improve QWL are required for the overall organizational development. In the result of data analysis, we find consistency that there exists a positive and significant relationship between each dimension as well as overall QWL and employee commitment. Further it can be said that the providing better QWL would also serve as a retention strategy and the key personnel would serve in a better way to reach business goals and attain organizational effectiveness. An interesting finding shows that satisfaction with benefit plan is strongly correlated with employee commitment and the correlation between workload and employee commitment scored the lowest.

The benefits of QWL initiatives are realized by both, employees and employers. Employees believe that having the good quality of work life has helped them grow in their professions as they feel safe and satisfied at work. According to the employers; with better QWL practices they can retain the human capital. Therefore, QWL is seen as a great retention strategy too. 


\section{Conclusion}

The study has established that QWL, organizational commitment and employee engagement are positively related, however, all dimensions of QWL are not uniformly related with organizational commitment and employee engagement. Different dimensions of QWL have distinct influence on these two constructs. Findings are consistent with previous studies (Huang et al., 2007).

The study highlights the quality of work life of Telecom employees under various dimensions. The findings clearly suggest that the increase in the practice of Quality of work life may increase the organizational commitment and engagement at individual levels. It is especially important to point again to the fact that a high quality of working life is one of the most important factor to reach the goals of achieving organizational effectiveness. Improvement in QWL is a source of numerous gains. It might lead to improve positive feelings towards one's self (greater self-esteem), towards one's job (improved job satisfaction and engagement), and towards the organization (strong organizational commitment).

The findings and results of the study have provided answers to the research objectives. This study provides valuable information about how employees in organizations view the work environment and how it can be improved to influence the commitment levels and enhance employee engagement in the organization. Therefore, this would help the organizations to direct resources and energy on those aspects that could make a considerable difference in the work life of employees. There is a need to create jobs that are more meaningful, which can induce commitment and give a greater personal stimulus ensuing in employee engagement.

Saudi employees are ambitious and look for improvements in the ways organization works and being young (90 percent were below 40 years); they are more receptive to change. Having proficient strategic human resource management with employee friendly policies would serve as a prerequisite to desirable QWL among Telecom professionals resulting in high level of commitment and engagement, whereas poor practices and policies can negatively affect the QWL, which may eventually fail the organizations' vision. The finding and results of the study would also have significant implications for the managers of this industry, who are responsible to meet the quality of work life expectation of employees and retain their commitment. This study has proved to understand the existing quality of work life and when efforts are invested to improve the existing QWL it would result in greater organizational effectiveness.

Acknowledgement: The author would like to acknowledge Business, Society \& Environment (BSE) Research Lab, Prince Sultan University, Saudi Arabia for their support.

\section{References:}

Albdour, A. A., \& Altarawneh, I. I. (2014). Employee engagement and organizational commitment: Evidence from Jordan. International journal of business, 19(2), 192-212.

Allui, A., \& Sahni, J. (2016). Strategic Human Resource Management in Higher Education Institutions: Empirical Evidence from Saudi. Procedia-Social and Behavioral Sciences, 235, 361-371.

Bagozzi, R. P., \& Yi, Y. (1988). On the evaluation of structural equation models. Journal of the Academy of Marketing Science, 16(1), 74-94.

Bailey, C., Madden, A., Alfes, K., \& Fletcher, L. (2017). The meaning, antecedents and outcomes of employee engagement: A narrative synthesis. International Journal of Management Reviews, 19(1), 31-53. 
Bakker, A. B., \& Albrecht, S. (2018). Work engagement: current trends. Career Development International, 23(1), 4-11.

Ballou, B., \& Godwin, N. H. (2007). Quality of "work life": have you invested in your organization's future? Strategic Finance, 41-46.

Barak, M. E. M. (2016). Managing diversity: Toward a globally inclusive workplace. Sage Publications.

Bates, S. (2004). Getting engaged. HR Magazine, 49(2), 44-51.

Bhatnagar, J. (2007). Talent management strategy of employee engagement in Indian ITES employees: key to retention. Employee Relations, 29(6), 640-663.

Bragard, I., Dupuis, G., \& Fleet, R. (2015). Quality of work life, burnout, and stress in emergency department physicians: a qualitative review. European Journal of Emergency Medicine, 22(4), 227-234.

Brunetto, Y., Teo, S. T., Shacklock, K., \& Farr-Wharton, R. (2012). Emotional intelligence, job satisfaction, well- being and engagement: explaining organisational commitment and turnover intentions in policing. Human Resource Management Journal, 22(4), 428-441.

Carlson, H. C. (1980). A model of quality of work life as a developmental process. In W. W. Burke and L. D. Goodstein (Eds.), Trends and Issues in OD.: Current Theory and Practice. San Diego, CA: University Associates, pp. 83-123.

Chalofsky, N., \& Krishna, V. (2009). Meaningfulness, commitment, and engagement: The intersection of a deeper level of intrinsic motivation. Advances in Developing Human Resources, 11(2), 189-203.

Chen, C. F. (2006). Job satisfaction, organizational commitment, and flight attendants' turnover intentions: A note. Journal of Air Transport Management, 12(5), 274-276.

Christian, M. S., Garza, A. S., \& Slaughter, J. E. (2011). Work engagement: A quantitative review and test of its relations with task and contextual performance. Personnel Psychology, 64(1), 89-136.

Danna, K., \& Griffin, R. W. (1999). Health and well-being in the workplace: A review and synthesis of the literature. Journal of Management, 25(3), 357-384

Deery, M. (2008). Talent management, work-life balance and retention strategies. International Journal of Contemporary Hospitality Management, 20(7), 792-806.

Denton, D. K. (1993). Using flextime to create a competitive workplace. Industrial Management, January/February, 29-31.

Dizaho, K. E., \& Othman, F. M. (2013, June). Antecedents of Work Life Balance and Its Impact on Loyalty, Satisfaction and Performance. Proceedings of the Global Conference on Business, Economics, and Social Sciences, 467-480.

Drobnic, S., Behan, B., \& Prag, P. (2010). Good job, good life? Working conditions and quality of life in Europe. Social Indicators Research, 99(2), 205-225.

Fornell, C., \& Larcker, D. F. (1981). Evaluating structural equation models with unobservable variables and measurement error. Journal of Marketing Research, 39-50.

Fu, W., \& Deshpande, S. P. (2014). The impact of caring climate, job satisfaction, and organizational commitment on job performance of employees in a China's insurance company. Journal of Business Ethics, 124(2), 339-349. 
Harter, J. K., Schmidt, F. L., \& Hayes, T. L. (2002). Business-unit-level relationship between employee satisfaction, employee engagement, and business outcomes: a meta-analysis. Journal of Applied Psychology, 87(2), 268.

Havlovic, S. J. (1991). Quality of work life and human resource outcomes. Industrial Relations: A Journal of Economy and Society, 30(3), 469-479.

Herzberg, F., Mausner, B., \& Snyderman, B. (1959). The Motivation to Work. New York: Wiley.

Hian, C. C., \& Einstein, W. O. (1990). Quality of Work Life: What can Unions do. Advanced Management Journal, 55(2), 17-22.

Hooper, N. (2006). Companies where people want to work. Weekend Australian Financial Review, 17-19.

Hu, Q., Schaufeli, W. B., \& Taris, T. W. (2011). The job demands-resources model: An analysis of additive and joint effects of demands and resources. Journal of Vocational Behavior, 79(1), 181-190.

Huang, T. C., Lawler, J., \& Lei, C. Y. (2007). The effects of quality of work life on commitment and turnover intention. Social Behavior and Personality: an International Journal, 35(6), 735750 .

Ibrahim, M., \& Al Falasi, S. (2014). Employee loyalty and engagement in UAE public sector. Employee Relations, 36(5), 562-582.

Johnson, G. (2004). Otherwise engaged. Training, 41(10), 4.

Kalra, S. K., \& Ghosh, S. (1984). Quality of work life-a study of associated factors. Indian Journal of Social Work, 45(3), 341-349.

Kanten, S., \& Sadullah, O. (2012). An empirical research on relationship quality of work life and work engagement. Procedia-Social and Behavioral Sciences, 62, 360-366.

Khaghanizadeh, M., Ebadi, A., \& Rahmani, M. (2008). The study of relationship between job stress and quality of work life of nurses in military hospitals. Journal Mil Med, 10(3), 175184.

Koonmee, K., Singhapakdi, A., Virakul, B., \& Lee, D. J. (2010). Ethics institutionalization, quality of work life and employees job related outcomes: A survey of human resource managers in Thailand. Journal of Business Research, 63, 20-26.

Kuo, T. H., Ho, L. A., Lin, C., \& Lai, K. K. (2010). Employee empowerment in a technology advanced work environment. Industrial Management \& Data Systems, 110(1), 24-42.

Lu, L., Lu, A. C. C., Gursoy, D., \& Neale, N. R. (2016). Work engagement, job satisfaction, and turnover intentions: A comparison between supervisors and line-level employees. International Journal of Contemporary Hospitality Management, 28(4), 737-761.

Martel, J. P., \& Dupuis, G. (2006). Quality of work life: Theoretical and methodological problems, and presentation of a new model and measuring instrument. Social Indicators Research, 77(2), 333-368.

Matzler, K., \& Renzl, B. (2006). The relationship between interpersonal trust, employee satisfaction, and employee loyalty. Total Quality Management and Business Excellence, 17(10), 1261-1271.

Meyer, J. P., \& Allen, N. J. (1997). Commitment in the Workplace: Theory, Research, and Application. Sage Publications.

Miller Jr, O. (2017). Employee turnover in the public sector. Routledge. 
Mirvis, P. H., \& Lawler III, E. E. (1984). Accounting for the quality of work life. Journal of Organizational Behavior, 5(3), 197-212.

Nachmias, D. (1988). The quality of work life in the federal bureaucracy: Conceptualization and measurement. The American Review of Public Administration, 18(2), 165-173.

Nadler, D. A., \& Lawler, E. E. (1983). Quality of work life: Perspectives and directions. Organizational Dynamics, 11(3), 20-30.

Nayak, T., Sahoo, C. K., \& Mohanty, P. K. (2018). Workplace empowerment, quality of work life and employee commitment: a study on Indian healthcare sector. Journal of Asia Business Studies, 12(2), 117-136.

Noor, S. M., \& Abdullah, M. A. (2012). Quality Work Life among Factory Workers in Malaysia. Procedia - Social and Behavioral Sciences, 35, 739-745.

O'Reilly, C. A., \& Chatman, J. (1986). Organizational commitment and psychological attachment: The effects of compliance, identification, and internalization on prosocial behavior. Journal of Applied Psychology, 71(3), 492-499.

Othman, A. K., Mahmud, Z., Noranee, S., \& Noordin, F. (2018, March). Measuring Employee Happiness: Analyzing the Dimensionality of Employee Engagement. International Conference on Kansei Engineering \& Emotion Research (pp. 863-869). Springer, Singapore.

Parkes, L. P., \& Langford, P. H. (2008). Work-life balance or work-life alignment? A test of the importance of work-life balance for employee engagement and intention to stay in organisations. Journal of Management \& Organization, 14(3), 267-284.

Ramstad, E. (2009). Promoting performance and the quality of working life simultaneously. International Journal of Productivity and Performance Management, 58(5), 423-436.

Reijseger, G., Peeters, M. C., Taris, T. W., \& Schaufeli, W. B. (2017). From motivation to activation: why engaged workers are better performers. Journal of Business and Psychology, 32(2), 117-130.

Rhoades, L., Eisenberger, R., \& Armeli, S. (2001). Affective commitment to the organization: The contribution of perceived organizational support. Journal of Applied Psychology, 86(5), 825-836.

Ringle, C. M., Wende, S., \& Will, A. (2005). Smart PLS 2.0. Hamburg: University of Hamburg.

Robinson, D., Perryman, S., \& Hayday, S. (2004). The Drivers of Employee Engagement Report. Institute for Employment Studies.

Che Rose, R., Beh, L., Uli, J., \& Idris, K. (2006). An analysis of Quality of work life and career related factors. American Journal of Applied Sciences, 3(12), 2151-2159.

Sahni, J. (2016). An assessment of Employee Perception Regarding Workplace Stress-Causes and Remedies: Evidence from Software Industry. International Journal of Management, IT and Engineering, 6(7), 23-39.

Sahni, J. (2017). Exploring what constitutes 'quality' in quality of work life for female employees. International Journal for Quality Research, 11(4), 785-798.

Saks, A. M. (2006). Antecedents and consequences of employee engagement. Journal of Managerial Psychology, 21(7), 600-619.

Schaufeli, W. B., Salanova, M., González-Romá, V., \& Bakker, A. B. (2002). The measurement of engagement and burnout: A two sample confirmatory factor analytic approach. Journal of Happiness Studies, 3(1), 71-92. 
Schaufeli, W. B. (2014). What is engagement? In C. Truss, K. Alfes, R. Delbridge, A. Shantz, \& E. Soane (Eds.), Employee Engagement in Theory and Practice. London: Routledge. What is engagement?

Seashore, S. E. (1975). Defining and measuring the quality of working life. The Quality of Working Life, 1, 105-118.

Sirgy, M. J., Efraty, D., Siegel, P., \& Lee, D. J. (2001). A new measure of quality of work life (QWL) based on need satisfaction and spillover theories. Social Indicators Research, 55(3), 241-302.

Stairs, M., \& Galpin, M. (2010). Positive engagement: From employee engagement to workplace happiness. In P. A. Linley, S. Harrington, \& N. Garcea (Eds.), Oxford library of psychology. Oxford handbook of positive psychology and work (pp. 155-172). New York, NY, US: Oxford University Press.

Steininger, D. J. (1994). Why quality initiatives are failing the need to address the foundation of human motivation. Human Resource Management, 33(4), 601-616.

Tabassum, A., Rahman, T., \& Jahan, K. (2011). A comparative analysis of quality of work life among the employees of local private and foreign commercial banks in Bangladesh. World Journal of Social Sciences, 1(1), 17-33.

Turkyilmaz, A., Akman, G., Ozkan, C., \& Pastuszak, Z. (2011). Empirical study of public sector employee loyalty and satisfaction. Industrial Management \& Data Systems, 111(5), 675-696.

Wagner, R., \& Harter, J. K. (2006). 12: The elements of great managing (Vol. 978, No. 1-59992). Simon and Schuster.

Wahlberg, T. A., Ramalho, N., \& Brochado, A. (2017). Quality of working life and engagement in hostels. Tourism Review, 72(4), 411-428.

Walton, R. E. (1973). Quality of working life: what is it?. Sloan Management Review, 15(1), 1121.

Walton, R. E. (1974). Improving the Quality of Work Life. Harvard Business Review, May-June, 12(a).

Xanthopoulou, D., Bakker, A.B., Demerouti, E., \& Schaufeli, W.B. (2007). The role of personal resources in the job demands-resources model. International Journal of Stress Management, $14,121141$.

Yao, T., Qiu, Q., \& Wei, Y. (2019). Retaining hotel employees as internal customers: Effect of organizational commitment on attitudinal and behavioral loyalty of employees. International Journal of Hospitality Management, 76, 1-8.

\section{Jolly Sahni}

Prince Sultan University,

P.O. Box 66833, Rafha

Street, Riyadh, 11586,

Saudi Arabia

jsahni@psu.edu.sa 